\title{
Will Investments in Human Resources During the COVID-19 Pandemic Crisis Pay Off After the Crisis?
}

\author{
In-Sue Oh \\ Department of Human Resource Management \\ Fox School of Business \\ Temple University \\ Philadelphia, PA 19122 \\ Phone: (215) 204-4112 \\ E-mail: insue.oh@temple.edu
}

\section{Joo Hun Han}

School of Management and Labor Relations

Rutgers, The State University of New Jersey

Piscataway, NJ 08854

Phone: (848) 445-9448

E-mail: jhan@smlr.rutgers.edu

In press at Industrial and Organizational Psychology: Perspectives on Science and Practice

Authors' note. Enquiries concerning this article should be sent to In-Sue Oh, Department of Human Resource Management, Fox School of Business, Temple University, 1801 Liacouras Walk, Philadelphia, PA 19122. Email: insue.oh@,temple.edu. Tel: (215) 204-4112. 
Rudolph et al. (2020), in their focal article, discussed two areas of strategic human resources (HR) policies/practices in which the COVID-19 pandemic crisis calls for action and attention from both HR managers and researchers. The first area is downsizing, which is unavoidable in many firms due to the immediate negative impact of the COVID-19 crisis on firm financial performance. The other area is online training, which deserves more attention due to the immediate need for educating employees for skills that are necessary to deal with the COVID-19 crisis. Whereas Rodolph et al. drew on evidence from research when they suggested that "HR managers should strive for a transparent and fair way of communication about downsizing measures" (p. XX), they did not provide evidence-based advice regarding the use of online training. Instead, given the lack of relevant research evidence, Rodolph et al. advanced an interesting research question - "empirical HR research will have to test if [investing in online training during the crisis] indeed pays off in increasing employee skills and productivity in the mid and long run" (p. XX). We believe that recent strategic HR research can provide some useful insights into this question, as discussed below.

Ployhart, Van Iddekinge, and MacKenzie (2011) discussed the ways in which staffing and training - two related yet distinct HR practices-are crucial for building human capital resources (defined as a firm-level aggregation of employee knowledge, skills, abilities, and other characteristics [KSAOs]). However, these two HR practices are directed toward two different types of human capital resources. Staffing is primarily directed toward generic human capital resources based on employees' general KSAOs (e.g., general mental ability, personality traits). In contrast, training primarily seeks to develop specific human capital resources based on employees' job- or firm-specific KSAOs. Thus, whereas staffing builds KSAOs that are valuable 
across various jobs and organizations, training develops KSAOs that are mainly valuable to a particular job or firm. Based on the resource-based view of the firm (Barney, 2001), Crook et al. (2011) argued and found that specific, rather than generic, human capital resources are neither readily tradable in labor markets nor are easy for other firms to imitate, and therefore contribute more to firm performance.

However, this perspective may not be valid when firms are experiencing unexpected shocks in their business environments. Crises like the Great Recession (December 2007-June 2009) and the COVID-19 crisis drastically disrupt firms' fit to their internal and external environments, and their success in post-crisis recovery may rest on their ability to enhance workforce flexibility and creativity. If true, the strategic value of specific and generic human capital resources may be reversed. As Kim and Ployhart (2014) discussed, "generic human capital resources can be redeployed or rebundled for different environments and purposes and are particularly important for building organizational flexibility and adaptability" (p. 366). However, specific human capital resources are unlikely to help build workforce flexibility and creativity due to their lack of transferability. That is, specific routines and skills inherent in specific human capital resources may function as organizational inertia, hindering workforce flexibility and creativity. Consistent with this logic, Kim and Ployhart (2014) found that firms that had invested more in staffing relative to their competitors recovered more quickly from the Great Recession. Pointedly, the same was not true of the firms that invested more in training.

Going back to the research question posed by Rodolph et al. (2020), it is likely that firms that invest in online training to address skill gaps during the COVID-19 crisis may not reap their 
benefit post-crisis if the training focuses on "skills and competencies that are helpful during the crisis (e.g., health and safety-relevant trainings)" (p. XX). We should also consider the direct and indirect costs of implementation, and the potential that what small benefit is enjoyed could be offset by greater costs. However, if the training is balanced by emphasizing general skills as well, which can be transferrable to many different contexts and thus help to develop workforce flexibility, it will have a greater potential to contribute to the firm's quick recovery and performance after the crisis. Thus, while firms in the current circumstances may be tempted to prioritize immediate skill needs in designing online training, if they are also seeking longerterm, post-crisis benefits of the training, they would need to find a way to incorporate elements that can help build generic human capital resources.

Additionally, firms' consistent investments in training for generic human capital resources (that may not benefit them immediately), regardless of their financial conditions and other situational factors, will likely signal that they care about and value employee contributions. This consistency helps to foster a long-term, trust-based relationship with employees that will be beneficial for a post-crisis rebound (Bowen \& Ostroff, 2004). Although the primary tool for building general human capital resources is staffing, training can also be used to develop generic human capital resources (e.g., training programs designed to improve problem-solving and critical thinking, how to work in challenging work assignments), and staffing practices can also be used to acquire specific human capital resources (e.g., targeted staffing, use of contingent professional workers).

Going forward, more research is needed to explore other HR practices (e.g., staffing, compensation, empowerment, information sharing). For example, it will be interesting to 
empirically examine whether firms that continue to hire during the COVID-19 crisis will recover from the crisis more quickly by strengthening generic human capital resources through careful staffing. Another interesting research question is how can firms effectively communicate with employees using various remote communication tools? Will such firms recover more quickly from the COVID-19 crisis by enhancing employees' collective perception of involvement and participation? It will also be interesting to empirically examine whether firms that avoid pay cuts and furloughs during the COVID-19 crisis, despite their immediate financial benefits, tend to recover more rapidly. In particular, the answer to the last research question can be quite tricky. These types of investments in HR often involve significant expenditures and profit reduction, which may be viewed negatively in the eyes of investors and shareholders, negatively impacting the stock price of the firm. However, it may also enhance the public relations of the firm and improve the firm's overall reputation among customers and investors who value corporate social responsibility (Aguinis, Vassar, \& Wayant, in press). ${ }^{1}$ Further, decades of I-O psychology research suggest that such a move will enhance employees' perceptions of organizational support and collective commitment to the firm, thereby increasing workforce productivity (Rhoades, Eisenberger, \& Armeli, 2001). Thus, it is important to broaden the criterion domain and examine the extent to which investments in various HR practices (designed to improve employees' performance and commitment to their job and firm) during the COVID-19 crisis pay off by improving various post-crisis firm outcomes (e.g., human

\footnotetext{
${ }^{1}$ Relatedly, Aguinis et al. (in press) lamented that "the specific HRM theories that can be used to improve our understanding of the relation between CSR and COVID-19 (and potential future pandemics and natural disasters) are also still unknown" (p. 14, parenthetical phrase in original). This suggests that future research along this line will be fruitful.
} 
capital resources, collective employee motivation and involvement, turnover rate, productivity, profitability, and market responses to the firm such as stock price) in order to better gauge the posit-crisis impact of HR investments during the COVID-19 crisis. It is also equally important to explore relevant boundary conditions and intervening mechanisms to deepen our understanding of this important issue. 


\section{References}

Aguinis, H., Villamor, I., \& Gabriel, K. P. (in press). Understanding employee responses to COVID-19: A behavioral corporate social responsibility perspective. Management Research.

Barney, J. B. (2001). Is the resource-based "view" a useful perspective for strategic management research? Yes. Academy of Management Review, 26, 41-56. https://doi:10.5465/AMR.2001.4011938

Bowen, D. E., \& Ostroff, C. (2004). Understanding HRM-firm performance linkages: The role of the "strength" of the HRM system. Academy of Management Review, 29(2), 203-221. https://doi.org/10.5465/amr.2004.12736076

Crook, T. R., Todd, S. Y., Combs, J. G., Woehr, D. J., \& Ketchen, D. J. (2011). Does human capital matter? A meta-analysis of the relationship between human capital and firm performance. Journal of Applied Psychology, 96, 443-456. https://doi:10.1037/a0022147

Kim, Y., \& Ployhart, R. E. (2014). The effects of staffing and training on firm productivity and profit growth before, during, and after the Great Recession. Journal of Applied Psychology, 99, 361-389. https://doi.org/10.1037/a0035408

Ployhart, R. E., Van Iddekinge, C. H., \& MacKenzie, W. I. (2011). Acquiring and developing human capital in service contexts: The inter- connectedness of human capital resources. Academy of Management Journal, 54, 353-368. https://doi.org/10.5465/AMJ.2011.60263097

Rhoades, L., Eisenberger, R., \& Armeli, S. (2001). Affective commitment to the organization: The contribution of perceived organizational support. Journal of Applied Psychology, 86(5), 825-836. https://doi.org/10.1037/0021-9010.86.5.825

Rudolph, C., Allan, B., Clark, M., Hertel, G., Hirschi, A., Kunze, F., ... \& Zacher, H. (2020). Pandemics: Implications for research and practice in industrial and organizational psychology. Industrial and Organizational Psychology: Perspectives on Science and Practice. 